\title{
Strategies in Power Relations in a Fictional Work: A Foucauldian Analysis
}

\author{
Gartika Rahmasari $^{1}$, Iis Kurnia Nurhayati ${ }^{2}$ \\ gartika.rahmasari@gmail.com ${ }^{1}$, iiskurnian@gmail.com ${ }^{2}$ \\ Universitas BSI Bandung ${ }^{1}$ \\ Telkom University Bandung ${ }^{2}$
}

\begin{abstract}
In a family, power relations can be seen in a father-child relationship, where the father has the authority to control the life of the child and the child must approve the father's decision. Not only the father, however, the son might also have different objective that he wants to achieve. Here both parties will usually try to keep pursuing their own objectives. In other words, both parties will look for strategies of how to win their objective in the power relation by acting certain ways. Hence, strategy can be used as the means to obtain victory (Foucault, 2002). The purpose of this paper is to analyze power relations that occurred in a family in a fictional work, namely Family Matters novel by Rohinton Mistry, particularly between Nariman Vakeel and his father, Marzi Vakeel. Nariman's objective is to acquire his father's approval for his desire to marry his girlfriend, Lucy Braganza, who is a Catholic. This is the opposite of Marzi's belief, that his family should marry a Parsi. Power relations and strategies used between Nariman and his father were examined using the theory of power relations from Michel Foucault. The findings show that each character implements different strategies in imposing power and confronting each other. As for Nariman, his strategies include persuading his father, and when this does not work, he started to show a clear insubordination every time. On the other hand, Marzi's strategies include writing a letter to newspaper to let other people know his opposition to interfaith marriage, objecting Lucy's presents in his house by rejecting Nariman's suggestion to invite Lucy over for dinner, and being patience in confronting Nariman's insubordination for eleven years. During these years, Marzi never utilized violence. In the end, Marzi succeeded in achieving his objective to make Nariman marry a Parsi woman when Nariman was finally tired of confronting his father, and let his father choose a Parsi woman. Nariman ended up having an arranged marriage.
\end{abstract}

Keywords: Family, Foucault, power relation, strategies

\section{Introduction}

Power relations can occur anywhere. According to Nelson \& Quick in Rahmasari (2016), power is one's ability to affect others. Power can only be affective if it is implied in a relation. According to Foucault (2002), power relations are a set of actions upon other actions.

The implementation of power in the simplest institution can be found in a family (Rahmasari, 2016). In a family, there are "mix tradition conditions, legal structures, matters of habit or fashion" (Foucault, 2002: 324), where the father is accepted as an absolute power holder for the son. If what the father wants something that is acceptable by his son, for example, then his son will happily obey the father's order. However, sometimes what the father wants does not always comply with what his son wants. In fact, to make the son to comply with what the father wants, there is a process of bargaining between the father and his son. Here both parties usually will try to keep pursuing their own objective. In other 
words, both parties will look for strategies of how to win their objective in the power relation by acting certain ways.

The purpose of this article is to analyze strategies in power relations that occurred in a family in a novel, namely Family Matters by Rohinton Mistry (Mistry, 2002). Power relations will be examined using the theory of Power Relations from Michel Foucault (2002).

\section{Theory and Method}

\section{Foucault's Power Relation}

The notion of power became the main topic of Michel Foucault's works. Michel Foucault was known as a philosopher as well as historian. Particularly in Subject and Power (1982), Foucault explained everything about power thoroughly, including the definition of power, what constitutes power relations, and how to analyze power relations.

Power is a mode of action that does not act directly or immediately on others; it is a set of action upon other action (Foucault, 2002: 340). It is different from the use of violence that has immediate effect on someone or something. It is not power relation when someone is in chain subject to violence, such as being beaten; power is when the chained man can be induced to speak, for example, although only a little (Foucault, 2002: 324). Power is a set of actions on possible actions; it incites, it induces, it seduces, it makes easier or more difficult, it constrains or forbids absolutely (Foucault, 2002: 341). Furthermore, when there is power, there is also resistance (Foucault, 1990). The field of power-relations makes for uneven territory where a constant set of tensions and fractured alliances, of flexible and adaptive maneuvers, its endless dynamic of forces and resistances cannot be reduced to the concise formulations of single or binary logics of force (Hook, 2007: 78). All power-relations, furthermore, may be treated as constraining on both sides (Hook, 2007: 79).

Moreover, Foucault stated that there is connection between power and government, as stated below:

Basically, power is less a confrontation between two adversaries or their mutual engagement than a question of "government". "Government" did not refer only to political structures of to the management of states, rater, it designated the way in which the conduct of individuals or of groups might be director -the government of children, of souls, of community, of families, of the sick. To govern, in this sense, is to structure the possible field of action of others. (Foucault, 2002: 341)

One of the characteristics of power is that it is repressive (2002: 120). Meaning, power can make someone follow the instruction of other party who exerts power over him/her, either voluntarily or by force. However, in power relation, it is not power if one immediately follows one's orders, like slavery.

\section{Strategies in Power Relations}

Power relation occurs between two parties. In a power relation, each party has their own objective. Hence, they might do whatever it takes to dominate the other party in order to pursue their objective. In other word, they might implement certain strategies in the power relation. In a power relation, strategy can be used in three methods, one of them is as the means to obtain victory (Foucault, 2002). Moreover, Foucault stated that "strategy ... (is used) to designate the procedures used in a situation of confrontation to deprive the opponent of his means of combat and to reduce him to giving up struggle" (Foucault, 2002: 346). Every strategy of confrontation dreams of becoming a relationship of power and every 
relation of power tends, both through its intrinsic course of development and when frontally encountering resistances, to become a winning strategy (Foucault, 2002: 347).

One of the important elements in power relation is freedom. Power is exercised only over free subjects, and only insofar as they are "free" (Foucault, 2002: 342). It means, the subjects have many possibilities to act and react towards other action in power relation, unlike slavery that cannot be called as power relation because slaves have no choice of how to act or behave except to obey any rules that are imposed to them.

\section{Content Analysis}

This research is a qualitative research with content analysis as a research method. Content analysis goal is purely descriptive, allowing the identification of patterns and frequencies of occurrences (Carlson, 2008). In this paper, content analysis is conducted in three steps: discussing the concept of power relations by Foucault, discussing strategies in power relations, and making connection between the concept of power relations as well as the strategies of power relations with the power relations experienced by the characters in the novel.

\section{Findings and Discussion}

In Family Matters, the discussion of the presentation of power relations will focus on the power relations that occur between Nariman and his father. In relations between family members, Nariman's father, Marzi, seemed to dominate more.

The main problem faced and the main cause of the implementation of power to Nariman was the difference in principles that Nariman and his father had in terms of choosing Nariman's spouse, namely the principle held by the family that Nariman should only marry a woman who was from the Parsi group like Nariman family. Parsis are people who follow Iranian prophet Zoroaster (or Zaratustra) and worship fire. This principle was not acceptable to Nariman because he liked Lucy Braganza who was a Catholic.

\section{Strategies of Marzi Vakeel (Father)}

The main problem faced and the main cause of the implementation of power by Marzy to Nariman was the difference in principles that Marzy and his son had in terms of choosing Nariman's spouse, namely the principle held by the family that Nariman should only marry a woman who was from the Parsi group like Nariman family. Parsis are people who follow Iranian prophet Zoroaster (or Zaratustra) and worship fire. This principle was not acceptable to Nariman because he liked Lucy Braganza who was a Catholic.

The issue of Marzi's rejection of Lucy, who is a Catholic, was further emphasized when he reacted to the news about the existence of interfaith marriage by writing a letter through a newspaper that showed his resistance to interfaith marriage. Marzi often related this problem to Lucy's problem, as quoted from the following narrator's statement.

"Invariably, his father would find a way to connect the controversy with Lucy. He would cite examples in it to illustrate why intermarriage was forbidden. Extracts from the correspondence would be presented as unshakeable arguments for prohibiting relationships between Parsi and non-Parsi." (Mistry, 2002: 113)

From the quotation above, it can be seen that Marzi made it clear about his objective that he is opposed to Nariman's wish to marry a non-Parsi woman, and that his act of writing letter to newspaper as his resistance to interfaith marriage is his way to repress Nariman. It can be pointed out as well that Marzi made attempt to bring interfaith marriage issue is a way to "strategy ... (used) to designate the procedures used in a situation of confrontation to 
deprive the opponent of his means of combat and to reduce him to giving up struggle..." (Foucault, 2002: 346).

Furthermore, Marzi said that Lucy "might be a wonderful person, as gracious and charming as the Queen of England, but she was still unsuitable for her son because she was not a Zoroastrian, case closed" (Mistry, 2002: 113). This is in accordance with the background of Marzi who was a Parsi who came from a conservative group. Marzi's rejection, when viewed from the Foucault concept, is a manifestation of "an action upon [Nariman's] action" (Foucault, 2002: 340). It is also a form of a strategy to repress Nariman.

No matter how hard and persistence Nariman tried struggled to confront his father in their power relation, Nariman finally gave up and stopped his efforts to continue with Lucy Braganza because it turned out his family, especially because Marzi was more persistent than himself.

"How naive, to have kept hoping his father would change his mind, or that a passive stance would avoid unpleasantness, improve the chances for Lucy and himself. He had underestimated his father's stamina, his willingness to trade familial happiness for narrow beliefs". (Mistry, 2002: 114)

Nariman relinquished his freedom by obeying his father's orders to marry a family choice woman after so long resisting. Nariman was tired of being constantly pressured by his family to immediately sever his relationship with Lucy Braganza, as seen in the narrator's statement: "They have been ground down by their families. Exhausted by the strain of it. He reminded himself how hopeless it is now ... What is purpose in continuing, letting it all crumble in useless bickering?" (Mistry, 2002: 14, emphasis from author)

In the quotation, it is implied that Marzi did not use violence as a means of applying power, but by using another, more subtle method: pressure, as indicated by the use of the word strain in the above quote. Over time, Nariman's belief that he would be able to marry Lucy finally faltered. Pressure made by his family made Nariman decided to surrender and end his struggle to defend Lucy, as written in the following narrator's statement:

" $[\mathrm{H}] \mathrm{e}$ thought about the eleven years he and Lucy had struggled to create a world for themselves. A cocoon, she used to call it ..., and after their families had forgotten their existence, they would emerge like two glistening butterflies and fly away together ..." (Mistry, 2002: 13)

The pressure imposed by Marzi can be seen as a strategy as well as the means to obtain victory (Foucault, 2002), where he keeps on pressing Nariman with his stance that Nariman was not allowed to marry a non-Parsi woman, although Nariman had tried to resist his father's wish and kept on seeing Lucy for 11 years. And for 11 years, Marzi continuously rejected Nariman's struggle to change his father's mind. Marzi strictly forbade him from marrying a Catholic woman. This is the application of the characteristics of power, that power "makes ... more difficult, ... constrains or forbids absolutely (Foucault, 2002: 341)

In power relation between Marzi and Nariman, it is obvious that Marzi is the winner of the battle. After eleven years of patience, Nariman's father succeeded to make Nariman give up Lucy. This can be seen from the following excerpt:

Much rejoicing had erupted with his parents announced their only son, after tears of refusing to end hi ill-considered liaison with that Goan woman, reusing to meet decent Parsi girls, refusing to marry someone respectable-that their beloved Nari had finally listened to reason and agreed to settle down. (Mistry, 2002: 13) 
Here, we can see that Marzi Vakeel implemented strategies and tacticts to reach his goals, which is to make Nariman, his son, marry to a Parsi woman. The implementation of his strategies is in line with Foucault who said that:

"[t]here is no power that is extended without a series of aims and objectives ... the rationality of power is characterized by tactics that are often quite explicit at the restricted level where they are inscribed ... tactics which, becoming connected to one another, attracting and propagating one another... (Foucault, 1980: 95)

\section{Strategies of Nariman Vakeel (Son)}

Although his father, Marzi, had shown a clear stand to oppose interfaith marriage, Nariman still tried to get his familyto receive Lucy Braganza, as stated in the following narrator's statement:

"Nariman tried to use the openings offered by breakfast discourses. He pleaded with his father to invite Lucy to lunch or tea, talk to her before making his mind up. But his father refused-it would be unfair, he said to raise the poor girl's hopes." (Mistry, 2002: 114)

From the above quote, it can be seen that Nariman tried to get his father to receive Lucy Braganza by suggesting that she invite Lucy to a family meal. Nariman's actions can be seen as Nariman's strategy to get his father's blessing regarding his choice. The desire to request this blessing can be seen as an act which indicates that Nariman was dominated by his father.

Nariman's suggestion to invite Lucy over to breakfast can be seen as a strategy in confronting his father's objection towards Lucy. This is in line with Foucault's statement that "Every strategy of confrontation dreams of becoming a relationship of power and every relation of power tends, both through its intrinsic course of development and when frontally encountering resistances, to become a winning strategy (Foucault, 2002: 347).

Marzi's rejection of Lucy did not make Nariman surrender. He remained in a relationship with Lucy in the hope that someday his family would melt and want to accept Lucy as a potential companion. Nariman's actions could be seen as a form of resistance to the application of power by Marzi: insubordination was carried out to maintain freedom so that Nariman could still choose Lucy as his life companion. Nariman's insubordination towards Marzi's action to forbid Nariman from having relationship with a Catholic woman can be seen as one of his strategies as well as "a winning strategy"(Foucault, 2002: 347).

On the other hand, Nariman did not want to give up his freedom to surrender to his father's order. For 11 years he insisted to be with Lucy Braganza and worked on various strategies to pursue his objective to marry her. Lucy also kept persuading him to fight to create the world of their own by comparing them as "a cocoon... A cocoon is what they needed ... into which they could retreat and after their families had forgotten their existence, they would emerge like two glistening butterflies and fly away together" (Mistry, 2002: 13).

In contrary to his expectation, his big family resisted Lucy altogether. Even his aunt said, "No happiness is more lasting than the happiness that you get from fulfilling your parents' wishes. Remember that, Nari" (Mistry, 2002: 13).

As the result of being "lost" in the power relation between Nariman and his father, Nariman accepted to marry a Parsi woman as arranged by his family, where usually women experience arranged marriage and are not given the authority to choose their own candidate. However, unlike what is usually experienced by women in India, in this case Nariman himself let his family take care of his marriage with the Yasmin Contractor, as written in the 
following quote: " Like an invalid steered by doctors and nurses, he drifted through the process, suppressing his doubt and misgivings, ready to believe that the traditional ways were the best." (Mistry, 2002: 17)

\section{Conclusion}

In power relation between Marzi Vakeel and his son, Nariman Vakeel, both of the characters operated their own strategies in confronting each other. Marzi has his own strategies in controlling Nariman. To begin with, Marzi's strategy was making a clear statement about how he opposed interfaith marriage, by writing for a newspaper where everyone could read and knew where he stood about Nariman's stance. Next, Marzi did not use violence as his strategy to make Nariman obey him to marry a Parsi woman, nor did he talk down about Lucy. Instead, he would talk about Lucy in descent way, but in the end he would remind Nariman that Lucy was unsuitable for their family, no matter how gracious or wonderful Lucy was as a person. Marzi was continuously being patience in addressing Nariman's insubordination in 11 years of Nariman's struggle to win their power relation, which later repressed Nariman and made him give up.

On the other hand, Nariman implemented several strategies. At first, he persuaded his father by suggesting to invite Lucy over for dinner to give Marzi a chance to get to know Lucy better. When this strategy was rejected, Nariman started to utilize another strategy, a clear insubordination, as a way to win over his father in their power relation. He would continuously do opposite thing as what his father told him.

After eleven years of power relations between Nariman and his father, it is obvious that it was his father, Marzi, who won the battle. After all actions and reactions imposed over each other's strategies, Nariman surrendered and ended up having an arranged marriage where he married a Parsi woman chosen by his father.

\section{References}

Balan, Sergiu. 2010. M. Foucault's View on Power Relations. Cogito. Multidisciplinary Research Journal. II. 55-61.

Carlson, Les. 2008. Use, misuse, and abuse of content analysis for research on the consumer interest. The Journal of Consumer Affairs, 42(1), 100-105.

Foucault, M. 1980. Two lectures. In C. Gordon (ed.), Power/knowledge: Selected Interviews and Other Writings by Michel Foucault. New York: Pantheon Books, 78-108.

Foucault, M. 1990. The History of Sexuality: An Introduction. New York: Vintage Books.

Foucault, M. 2002. Power: Essential Works of Foucault 1954-1984 (Volume 3). Penguin Books.

Hook, D. 2007. Foucault, Psychology and the Analytics of Power. New York: Palgrave Macmillan.

Lock, E. 2009. Soft power and strategy: Developing a 'strategic'conception of power. In: Parmar, I. and Cox, M., eds. (2009) Softpower and US foreign policy: Theoretical, historical, and contemporary perspectives. Routledge, 32-50.

Powell, Jason L. 2015. Foucault, Power and Culture. International Journal Of Humanities And Cultural Studies, 1(4), 401-419.

Rahmasari, G. 2016. Penyajian Relasi Kekuasaan dalam Novel A Fine Balance Karya Rohinton Mistry. Konferensi Nasional Ilmu Sosial \& Teknologi (KNIST), 110-115. 